Agro-Science Journal of Tropical Agriculture, Food, Environment and Extension

Volume 11 Number 1 Januarv 2012 nn 43 - 54

ISSN 1119-7455

\title{
SEASONAL DYNAMICS OF SOIL ORGANIC MATTER AND TOTAL NITROGEN IN SOILS UNDER DIFFERENT LAND USES IN OWERRI, SOUTHEASTERN NIGERIA.
}

\author{
Agim, L.C. ${ }^{1}$, Osuji G.E ${ }^{.1}$, Onweremadu E.U. ${ }^{1}$, Ndukwu B.N. ${ }^{1}$, and Osuaku, S.K ${ }^{2}$. \\ ${ }^{1}$ Department of Soil Science and Technology, Federal University of Technology P.M.B 1526, \\ Owerri, Imo State, Nigeria. \\ ${ }^{2}$ Department of Soil Science, Imo State University Owerri., Nigeria.
}

\begin{abstract}
:
The study investigated seasonal dynamics of soil organic matter and total nitrogen in soils affected by different land use types in Owerri, Southeastern Nigeria. A total of 72 soil samples were randomly collected at two monthly intervals in the dry season (October/November, December/January and February/March) and rainy season (April/May, June/July and August/September) at 0-20 cm depth in all the studied land uses, namely soils under continuous cassava cultivation (CCS), pineapple orchard soil (POS), bush fallow (FS) and bare fallow (BF.) . Collected soil samples were air dried, passed through $2 \mathrm{~mm}$ sieve and were analysed using standard methods. The experiment was factorially arranged in randomized complete block design (RCBD), with three factors namely, season, month and landuse. The treatments were replicated three times. Generated soil data were analysed using analysis of variance (ANOVA) and significant means were separated using least significant difference (LSD) at 5\% probability. Results showed that soil organic matter and total nitrogen were significantly higher $(P<0.05)$ in the dry season especially between January and April compared to the rainy season where the least was found around June/July in all the studied land uses, although in all cases, their variability was minimal, ranging from $30.49 \%$ in (CCS) to $47.68 \%$ in bare fallow. Significant positive correlation $(P<0.05)$ was found between soil organic matter (SOM) and total nitrogen $\left(r^{2}=0.966\right.$ CCS; 0.935 FS, 0.626 POS, and $\left.0.796 \mathrm{BF}\right)$, and negative correlation with $\mathrm{CN}$ ratio $\left(r^{2}=0.917 \mathrm{CCS} ; 0.729 \mathrm{FS}, 0.3 \mathrm{POS} ; 0.347 \mathrm{BF}\right)$, respectively, bulk density $\left(r^{2}=0.63\right)$ only in FS. Similarly significant negative correlations $(P<0.05)$ were also found between TN and CN ratio $\left(r^{2}=0.865 \mathrm{CCS}, 0.716 \mathrm{FS}, 0.796 \mathrm{POS}\right.$ and $\left.0.328 \mathrm{BF}\right)$.
\end{abstract}

Key words. Tropical soil, seasonal variability, total nitrogen, organic matter, land use, Southeasthern Nigeria.

\section{INTRODUCTION.}

Soil organic matter is a product of plant and animal materials that have undergone decomposition process (Bot and Benites, 2005); and is one of the major earth's carbon reservoirs, storing around $1.5 \times 10^{18} \mathrm{~g}$ of carbon (Xiao, 1999), which is slightly more than twice the amount of carbon present in the atmosphere as $\mathrm{CO}_{2}$ (Jackson, 2000). Organic matter stored in soil apart from affecting crop production plays very critical role in global carbon balance which is a major factor in regulating global warming, or the greenhouse effect (Eswaran et al., 1993, Batjes, 1999). Soil organic matter and nitrogen in the soil are strongly linked (DabekSzreniawska and Balashov, 2007), because proper decomposition of the former releases nitrogen in the form of ammonium to the soil (Singer and Munns, 1999), apart from other nitrogen from such sources as atmospheric deposition, symbiotic fixation, and redistribution within the soil profile (Knops and Tillman, 2000). Although the status of organic matter and nitrogen in soils is taken as an indicator of soil fertility, these important soil properties change with season and land use practices. Seasonal dynamics of soil organic matter and nitrogen are directly linked with temperature changes, soil moisture availability, soil organism, carbon nitrogen ratio of the decomposing material, oxygen content of soil, type of material added to the soil and stage of decay (Singer and Munns 1999; Brady and Weil 1999). Soil organic matter is readily available in the soil when the soil is not near saturation such that aerobic condition that favours soil organisms prevails (Bot and Benites, 2005). 
Agricultural land use practices can cause the loss of a large fraction of soil organic matter and nitrogen thus making them not available to plants (Tiessen et al., 1982; Mann) 1986; Schlesinger, 1986). Population pressure on land leading to an increase in the amount of land in agriculture over the past 200 years has led to a decrease in organic carbon stored in soils and a net release of carbon into the atmosphere thus causing global warming. When nitrogen is lost from the soil through runoff as a result of land misuse into fresh water, it causes eutrophication (Howarth et al., 1996). Additionally, Yao et al, (2010) observed a considerable decline of soil organic carbon, cation exchange capacity (CEC), $\mathrm{pH}$, particle size distribution, calcium carbonate content, base saturation and bulk density when forest land was converted to agricultural use. Seasonal variation in soil organic matter and nitrogen has been extensively studied both in the temperate and tropical areas (Angers, 1992; Leinweber et al., 1994; Crocker and Holford, 1996; Hendrix, 1997; Mahmood et al., 1997; Kieft et al., 1998; Knops and Tilman 2000; Dabek-Szreniawska and Balashov, 2007). Soil orgaic matter and nitrogen have also been studied with respect to their storage (Anikwe, 2010) and effects of land use (Yao, et al., 2010), but there is little or no work done on them with respect to the selected landuses, and sampling months Some scholars (Agboola and Corey, 1973; Woomer and Ingram, 1990) opined that the fertility status of most soils in the humid tropics, particularly under low input agricultural systems, depends largely upon soil organic matter (SOM), both quantitatively and qualitatively. Thus an understanding of organic matter and nitrogen dynamics in soils of the area can be useful in characterizing different practices with a view to sustaining agricultural development owing to the large population of farmers in the area.

Based on the above, the major objective of this study was to determine the seasonal dynamics of soil organic matter and total nitrogen in soils under different landuses in Owerri Southeastern Nigeria. Specific objectives were to determine the effect of land use on organic matter and total nitrogen in the studied soil and to determine the relationship that exists between SOM and TN in the landuse types.

\section{MATERIALS AND METHODS.}

Study area: This study was carried out at Federal University of Technology Teaching and Research Farm Owerri, Imo State in Southeastern Nigeria. The farm is located on Latitude $5^{0} 22^{1} 55.5^{11} \mathrm{~N}$ and Longitude $6^{0} 59^{1}$ $39.3^{11} \mathrm{E}$ on an elevation of $61 \mathrm{~m}$ above sea level. The soils are derived from Coastal Plain Sands
(Benin formation) (Orajaka, 1975). The existing vegetation is secondary forests (Igbozuruike, 1975). The area belongs to the humid tropics with two seasons (dry and rain/ wet); minimum and maximum ambient temperatures of $20^{\circ} \mathrm{C}$ and $32^{\circ} \mathrm{C}$ and is characterized with annual rainfall of about $2500 \mathrm{~mm}$ biomodially distributed with peaks in the months of July through September and a short period of dry season in August known as August break (Imo State, 1984).

Landuse types studied: They include a continuously cassava cultivated soil (CCS) which has been under cultivation with cassava for more than six years. A fallow soil (F.S) which has been under bush fallow for more than 7 years. A soil under pineapple orchard soil (P.O.S) of about 5 years and a bare fallow (B.F) without vegetation maintained by constant hand peaking of the weeds throughout the sampling period which also served as the control.

Soil Sampling: Random sampling technique was used in collecting soil samples. With soil augers, surface soil $0-15 \mathrm{~cm}$ depth were sampled, air dried, passed through $2 \mathrm{~mm}$ sieve for routine laboratory analysis. Sample collection was carried out at two monthly intervals from January to December 2009 to cover the two seasons as follows: October/November, December/ January, February/March, (Dry Season) April/ May, June/July, August/September (Rainy season). This covers a total of 6 sampling periods. At each sampling period, 12 samples were collected in three replicates each from all the land uses which gave rise to a total of 72 soil samples. Core rings were used to collect undisturbed soils for bulk density determination

Experimental design: The experiment was factorially arranged in randomised complete block design (RCBD), with three treatments namely: Season, Month and Landuse to give rise to 3-factor factorial experiment. The four landuses CCS, FS, POS and BF, constituted the main factor; while the sub factor treatments were seasons (dry and rainy) and months of sampling, respectively.

Laboratory analysis: Particle size distribution was determined by the hydrometer method according to the procedure of Gee and Or (2002). Moisture content (M.C) was determined gravimetrically according to the procedure of (Obi ,1990).Bulk density ( $\ell b)$ was measured by the core methods (Grossman and Reinsch, 2002). Total porosity was calculated using a mathematical relationship between bulk density and particle density as 
Agim, L.C. ${ }^{1}$, Osuji G.E ${ }^{1}$, Onweremadu E.U. ${ }^{1}$, Ndukwu B.N. ${ }^{1}$, and Osuaku, S.K ${ }^{2}$.

1 - Bulk density( (b) x100. (Forth, 1984).

Particle density.

Soil $\mathrm{pH}$ was measured potentiometrically in 1:2.5 soil-water ratio (Hendershot et al., 1993). Organic carbon was determined by the procedure of Nelson and Somers 1982) while soil organic matter was got by multiplying organic carbon with a factor of 1.742 . Total nitrogen was determined by Microkjeldahl digestion method using concentrated $\mathrm{H}_{2} \mathrm{SO}_{4}$ and a sodium copper sulphate catalyst mixture ( Bremner, 1996). Exchangeable bases were determined by ammonium acetate leaching and exchangeable acidity by titration (McLean, 1982), effective cation exchange capacity (E.C.E.C) was obtained by the summation of all exchangeable bases and exchangeable acidity (Landon, 1991).

Data analyses: Data were analyzed using analyses of variance (ANOVA). Least significant difference (LSD) was used in separating significant means at 5\% probability. Correlation and regression were carried out using Microsoft excel office suit 2007 edition.

\section{RESULTS AND DISCUSSION.}

Soil physical property: Mean values of physical and chemical properties of the soil are presented in Tables 1 and 2, respectively. The texture of the studied soils are all sandy loam irrespective of land use and season. This corroborates the findings of Onweremadu et al, (2008). Sandy fraction ranges from $570.15 \mathrm{~g} / \mathrm{kg}$ in BF to $826.95 \mathrm{~g} / \mathrm{kg}$ in FS. Clay and silt range from 125.73 in POS to $248.52 \mathrm{~g} / \mathrm{kg}$ in FS and $45.50 \mathrm{~g} / \mathrm{kg}$ in FS to $157.60 \mathrm{~g} / \mathrm{kg}$ in CCS repectivedy. Sandiness of these soils is due to a combination of sandy parent material (Coastal Plain Sands), tropical climate and land use (Onweremadu, 2007), and high precipitation in the area resulting to clay lessivage (UnambaOpara et al., 1987; Eshett et al., 1990; Chukwuma et al., 2010). These factors influence pedogenesis and properties of soils (Akamigbo, 1999; Wang et al., 2001). However, while total sand and silt were significantly higher $(p<0.05)$ in dry season, silt fraction was higher in rainy season. This could be attributed to rainfall which detaches sand particles easily. Clay fraction could not follow a particular trend but was significantly higher in dry season in CCS and BF only. This change could be attributed to illuviation of clay (Akamigbo, 1983). Bulk density was significantly higher $(\mathrm{P}<0.05)$ in rainy season in all the studied landuse, being $1.23-1.37 \mathrm{~g} / \mathrm{cm}^{3}$ CCS; $1.33-1.37 \mathrm{~g} / \mathrm{cm}^{3}$ in FS; $1.29-1.33 \mathrm{~g} / \mathrm{cm}^{3}$ in POS and $1.41-1.39 \mathrm{~g} / \mathrm{cm}^{3}$ in $\mathrm{BF}$ The values of bulk density were in line with the ranges documented by Landon (1991) for tropical soils. Onweremadu et al. (2007),
Achmad et al. (2003) and Scot et al. (1994) found higher bulk densities during rainy season. Seasonal changes in bulk density are attributed to heavy annual rainfall that lasts for about 9 months and estimated to be $2500 \mathrm{~mm}$ thus clogging the pore spaces (Oti, 2002). Increased bulk density during the rainy season could also be attributed to reduced soil organic matter as a result of slow decomposition. Highest bulk density found in $\mathrm{BF}$ compared to other land use practices could be attributed to reduced organic matter as a result of scanty vegetation (Bot and Temites 2005), and direct impact of rain drop on the soil (Bresson et al., 2004). High bulk density leads to low porosity thus affecting the activities of aerobes which leads to poor microbial function in the soil, increased runoff, and uneasy penetration of roots. However, all the values of the bulk density will not compact the soil to the extent of affecting the potential use of the soil for farming activities since they are in the range documented by Landon, (1991).

Soil Chemical properties. Soil $\mathrm{pH}$ ranges from 4.46 to 6.49 in CCS; 4.49 to 6.32 in FS; 4.83 to 6.41 in POS, and 4.47 to 6.37 in BF respectively (Table 2.). Soil $\mathrm{pH}$ was significantly $(\mathrm{p}<0.05)$ lower in rainy season compared to dry season where it was higher (Figure 3). Onweremadu et al. (2007) recorded similar results in dry and rainy season. Lower values of $\mathrm{pH}$ recorded during the rainy season is attributed to high rainfall which would have washed the basic cations through leaching thereby leaving the acidic cations of hydrogen and aluminum in the soil. Soil organic matter was significantly $(\mathrm{P}<$ 0.05 ) higher in dry season in all the studied land uses (Fig.1). It ranged from $23.73 \mathrm{~g} / \mathrm{kg}$ in December/January to $9.75 \mathrm{~g} / \mathrm{kg}$ in June/July in CCS, $19.72 \mathrm{~g} / \mathrm{kg}$ in February/March to $5.50 \mathrm{~g} / \mathrm{kg}$ in June/July in FS, $27.10 \mathrm{~g} / \mathrm{kg}$ in December/January to $6.30 \mathrm{~g} / \mathrm{kg}$ in June/July in POS, and $20.23 \mathrm{~g} / \mathrm{kg}$ in December/January to $9.70 \mathrm{~g} / \mathrm{kg}$ in BF (Table 2.0). DabekSzreniawska and Balashov (2007) found similar results. Increased soil organic matter found during the dry season is attributable to increase temperature, decrease soil moisture content in the soil during dry season which invariably affects decomposition and further mineralization (Singer and Munns, 1999); high clay values found within this period (Bot and Benites, 2005). Again, the increased SOM found during the dry season corroborates the significant higher $\mathrm{pH}$ values found during the dry season. Continuously cultivated soil had significantly $(\mathrm{P}<0.05)$ higher organic matter compared to other land uses (Fig. 2), contrary to earlier documentations of Yao et al. (2010) that forest soils contributed more 


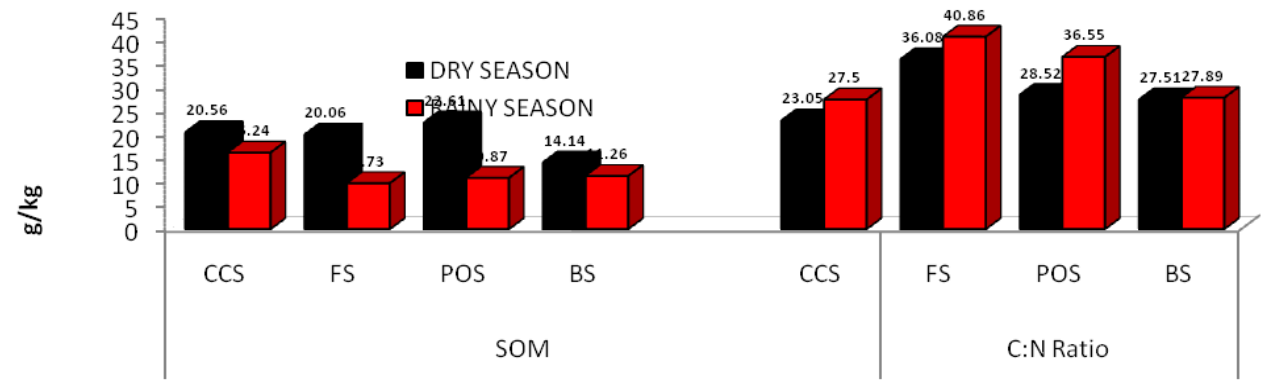

Fig. 1. Seasonal distribution of SOM and C:Ratio.

Table 1: Mean values of physical properties of studied soils.

\begin{tabular}{|c|c|c|c|c|c|c|c|c|c|c|c|}
\hline Soil & Unit & L.U & & Dry sea & & & Rainy & & & & \\
\hline & & & $\mathrm{O} / \mathrm{N}$ & $\mathrm{D} / \mathrm{J}$ & F/M & Mean & $\mathrm{A} / \mathrm{M}$ & $\mathrm{J} / \mathrm{J}$ & $\mathrm{A} / \mathrm{S}$ & Mean & \\
\hline LSD & $\mathrm{g} / \mathrm{kg}$ & $\mathrm{CCS}$ & 71.58 & 37.00 & 153.87 & 88.78 & 160.35 & 138.68 & 187.64 & 162.17 & NS \\
\hline$p<0.05$ & & & & & & & & & & & \\
\hline VMC & & & & & & & & & & & \\
\hline & & FS & 86.45 & 27.18 & 121.94 & 78.52 & 135.60 & 168.55 & 176.48 & 160.21 & NS \\
\hline & & POS & 80.08 & 21.87 & 63.48 & 55.15 & 123.92 & 168.33 & 239.65 & 177.30 & NS \\
\hline & & $\mathrm{BF}$ & 86.45 & 8.84 & 97.08 & 64.12 & 114.05 & 150.11 & 176.48 & 146.88 & NS \\
\hline & LSD $\mathrm{P}<0.05$ & & NS & NS & NS & NS & NS & NS & NS & NS & NS \\
\hline$\ell b$ & $\mathrm{~g} / \mathrm{cm} 3$ & CCS & 1.24 & 1.29 & 1.15 & 1.23 & 1.31 & 1.43 & 1.37 & 1.37 & $0.05^{*}$ \\
\hline & & FS & 1.42 & 1.30 & 1.27 & 1.33 & 1.31 & 1.39 & 1.43 & 1.37 & $0.05^{*}$ \\
\hline & & POS & 1.13 & 1.30 & 1.27 & 1.33 & 1.31 & 1.39 & 1.43 & 1.37 & $0.05^{*}$ \\
\hline & & $\mathrm{BF}$ & 1.43 & 1.47 & 1.32 & 1.41 & 1.34 & 1.40 & 1.43 & 1.39 & $0.05^{*}$ \\
\hline & LSDP $<0.05$ & & $0.06^{* *}$ & $0.06 * *$ & $0.06^{* *}$ & $0.04 *$ & $0.06^{* *}$ & $0.06^{* *}$ & $0.06 * *$ & $0.04 *$ & $0.08 *$ \\
\hline $\mathrm{TP}$ & $\%$ & CCS & 53.20 & 50.89 & 59.84 & 54.64 & 47.81 & 45.94 & 48.30 & 47.35 & NS \\
\hline & & FS & 45.91 & 51.03 & 51.98 & 49.64 & 50.64 & 47.54 & 45.87 & 48.02 & NS \\
\hline & & POS & 57.35 & 46.31 & 54.10 & 52.79 & 53.37 & 47.57 & 48.68 & 49.87 & NS \\
\hline & & $\mathrm{BF}$ & 45.98 & 48.87 & 50.36 & 48.40 & 49.28 & 51.19 & 45.87 & 48.78 & NS \\
\hline & LSDP<0.05 & & NS & NS & NS & $2.34 * *$ & NS & NS & NS & $2.34 * *$ & $4.68 * *$ \\
\hline Sand & & $\mathrm{CCS}$ & 700.88 & 701.35 & 728.28 & 710.17 & 666.16 & 660.69 & 6665.49 & 664.11 & $26.48 *$ \\
\hline & & FS & 723.16 & 826.95 & 709.81 & 753.30 & 739.75 & 715.09 & 630.27 & 695.03 & $26.48 *$ \\
\hline & & POS & 744.82 & 792.62 & 712.02 & 749.84 & 691.62 & 699.74 & 603.61 & 664.99 & $26.48 *$ \\
\hline & $\mathrm{g} / \mathrm{kg}$ & $\mathrm{BF}$ & 723.28 & 742.82 & 758.85 & 741.63 & 664.02 & 673.54 & 570.15 & 653.90 & 26.48 \\
\hline & LSDP $<0.05$ & & NS & NS & NS & $21.62 *$ & NS & NS & NS & $21.62 *$ & $52.96 * *$ \\
\hline & & CCS & 103.08 & 119.98 & 102.64 & 108.57 & 118.42 & 142.02 & 157.60 & 139.35 & $28.85^{* *}$ \\
\hline & & FS & 71.48 & 54.41 & 122.04 & 82.68 & 45.50 & 121.50 & 121.20 & 96.062 & $8.85^{* *}$ \\
\hline & & POS & 50.30 & 81.60 & 100.79 & 77.56 & 109.06 & 112.38 & 197.15 & 143.53 & $28.85^{* *}$ \\
\hline & & $\mathrm{BF}$ & 118.18 & 78.11 & 62.24 & 86.17 & 141.98 & 139.22 & 181.33 & 154.17 & $28.85 * *$ \\
\hline Silt & LSDP $<0.05$ & & NS & NS & NS & $23 . .56^{* *}$ & NS & NS & NS & $23.56^{* *}$ & NS \\
\hline & & $\mathrm{CCS}$ & 196.04 & 178.67 & 169.09 & 203.93 & 215.42 & 183.98 & 176.91 & 192.10 & $17.81 *$ \\
\hline & & FS & 205.30 & 118.64 & 168.15 & 164.03 & 193.06 & 163.41 & 248.52 & 201.66 & $17.81 *$ \\
\hline & & POS & 204.87 & 125.73 & 187.19 & 172.60 & 199.32 & 188.54 & 199.24 & 218.36 & $17.81^{*}$ \\
\hline & & $\mathrm{BF}$ & 118.18 & 78.11 & 62.24 & 86.17 & 141.98 & 139.22 & 181.33 & 154.17 & $28.85 * *$ \\
\hline & $\mathrm{LSD}<0.05$ & & NS & NS & NS & $23.56^{*}$ & NS & NS & NS & $23.56^{*}$ & NS \\
\hline Clay & & CCS & 196.04 & 178.67 & 169.09 & 203.93 & 215.42 & 183.98 & 176.91 & 192.10 & $17.81 *$ \\
\hline & & FS & 205.30 & 118.64 & 168.15 & 164.03 & 193.06 & 163.41 & 248.52 & 201.66 & $17.81 *$ \\
\hline & & POS & 204.87 & 125.73 & 187.19 & 172.40 & 199.32 & 188.54 & 199.24 & 218.36 & $17.81 *$ \\
\hline & & $\mathrm{BF}$ & 158.60 & 179.07 & 197.70 & 193.32 & 194.80 & 187.27 & 148.52 & 191.83 & $17.81 *$ \\
\hline & LSD $<0.05$ & & $20.57 *$ & $20.57 *$ & $20.57 *$ & NS & $20.57^{*}$ & $20.57 *$ & $20.57 *$ & NS & $29.09 *$ \\
\hline Textural & ass & CCS & SL & SL & SL & & SL & SL & SL & & \\
\hline & & FS & SL & SL & SL & & SL & LS & SL & & \\
\hline & & POS & SL & SL & SL & & & & & & \\
\hline & & $\mathrm{BF}$ & SL & SL & SL & & SL & SL & SL & & \\
\hline
\end{tabular}

$\mathrm{CCS}=$ Continuously cultivated soil, $\mathrm{FS}=$ Soil Under fallow, $\mathrm{POS}=$ Soil under pineapple cultivation, $\mathrm{BF}=\mathrm{Bare}$ fallow, $\mathrm{SL}=\mathrm{Sandy}$ loamy. $\ell \mathrm{b}=$ Bulk density, $\mathrm{VMC}=$ Volumetric moisture content, $\mathrm{LSD}=$ Least significant different, $* *=$ Highly significant, $*$ =significant, L.U= Land use; O/N=October/November, D/J= December $/$ January, F/M=February/March, A/M=April/May, J/J= June/July, A/S=August/September. 
Agim, L.C. ${ }^{1}$, Osuji G.E ${ }^{1}$, Onweremadu E.U. ${ }^{1}$, Ndukwu B.N. ${ }^{1}$, and Osuaku, S.K ${ }^{2}$.

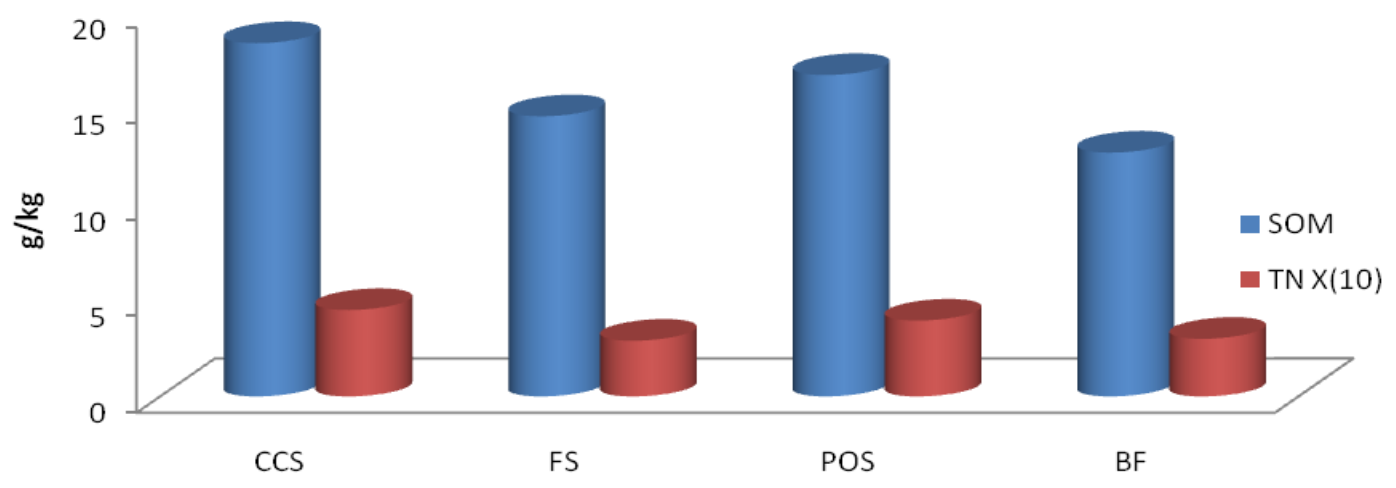

Figure 2. organic matter and total nitrogen distibution according to land use

Table 2. Mean values chemical properties of studied soils.

Soil property Unit L.U Dry season

Rainy season

\begin{tabular}{|c|c|c|c|c|c|c|c|c|c|c|c|}
\hline & & & $\mathrm{O} / \mathrm{N}$ & $D / J$ & $\mathrm{~F} / \mathrm{M}$ & MEAN & $\mathrm{A} / \mathrm{M}$ & $J / J$ & $\mathrm{~A} / \mathrm{S}$ & Mean & $\mathrm{LSD}_{0.05}$ \\
\hline \multicolumn{2}{|l|}{$\mathrm{pH}$ (water) } & $\mathrm{CCS}$ & 6.49 & 5.10 & 4.49 & 5.51 & 4.91 & 4.83 & 4.46 & 4.72 & $0.15^{* *}$ \\
\hline & & FS & 6.32 & 5.14 & 5.33 & 5.60 & 4.97 & 4.49 & 4.51 & 4.52 & $0.15 * *$ \\
\hline & & POS & 6.41 & 4.83 & 5.18 & 5.47 & 5.07 & 4.66 & 5.34 & 4.91 & $0.15 * *$ \\
\hline & & $\mathrm{BF}$ & 6.37 & 4.99 & 5.10 & 4.49 & 4.75 & 4.70 & 4.47 & 4.64 & $0.15^{*}$ \\
\hline & LSD $<0.0$ & $0.133^{*}$ & $0.133^{*}$ & $0.133 *$ & $0.094 * *$ & $0.13 *$ & $0.13^{*}$ & 0.13 & 0.094* & NS & \\
\hline \multirow[t]{5}{*}{ SOM } & $\mathrm{g} / \mathrm{kg}$ & CCS & 20.96 & 23.73 & 17.65 & 20.56 & 19.38 & 9.75 & 19.60 & 16.24 & NS \\
\hline & & FS & 12.04 & 16.40 & 19.72 & 20.06 & 14.33 & 5.50 & 10.30 & 9.73 & NS \\
\hline & & POS & 19.78 & 27.10 & 20.94 & 22.61 & 15.31 & 6.30 & 11.01 & 10.87 & NS \\
\hline & & $\mathrm{BF}$ & 5.56 & 20.23 & 16.63 & 14.14 & 15.59 & 9.70 & 8.50 & 11.26 & NS \\
\hline & $\mathrm{LSD}<0.05$ & $2.53^{*}$ & $2.53^{*}$ & $2.53^{*}$ & $1.79 *$ & $2.53^{*}$ & $2.53^{*}$ & $2.53^{*}$ & $1.79 *$ & $6.02 *$ & \\
\hline \multirow[t]{5}{*}{$\mathrm{TN}$} & $\mathrm{g} / \mathrm{kg}$ & CCS & 0.50 & 0.65 & 0.44 & 0.53 & 0.47 & 0.17 & 0.54 & 0.36 & $0.02 *$ \\
\hline & & FS & 0.33 & 0.40 & 0.47 & 0.40 & 0.31 & 0.07 & 0.17 & 0.18 & NS \\
\hline & & POS & 0.50 & 0.41 & 0.56 & 0.55 & 0.33 & 0.06 & 0.32 & 0.24 & $0.13 * *$ \\
\hline & & BS & 0.05 & 0.48 & 0.40 & 0.33 & 0.21 & 0.16 & 0.23 & 0.27 & NS \\
\hline & $\mathrm{LSDp}<0.0$ & & $0.01 *$ & $0.01 *$ & $0.01 *$ & $0.03 *$ & $0.01 *$ & $0.01 *$ & $0.01 *$ & $0.13^{*}$ & $0.02 *$ \\
\hline \multirow[t]{5}{*}{$\mathrm{CN}$} & ratio & $\mathrm{CCS}$ & 23.48 & 21.40 & 23.77 & 23.05 & 24.10 & 32.94 & 25.47 & 27.50 & NS \\
\hline & & FS & 27.35 & 23.74 & 24.34 & 25.14 & 36.08 & 52.72 & 33.80 & 40.86 & $2.32^{*}$ \\
\hline & & POS & 23.17 & 30.66 & 22.33 & 22.32 & 28.52 & 61.00 & 20.14 & 36.55 & $2.32 *$ \\
\hline & & BS & 67.52 & 24.46 & 38.68 & 24.05 & 27.51 & 29.01 & 27.15 & 27.89 & NS \\
\hline & LSDP $<0$. & & $2.31 *$ & $2.31^{*}$ & $2.31^{*}$ & $3.23 *$ & $2.31 *$ & $2.31 *$ & $2.31 *$ & $3.32 *$ & 3.04* \\
\hline \multirow[t]{5}{*}{ Av.P } & $\mathrm{mg} / \mathrm{kg}$ & $\mathrm{CCS}$ & 9.01 & 12.23 & 7.60 & 9.61 & 12.11 & 10.04 & 12.33 & 11.05 & NS \\
\hline & & FS & 16.62 & 16.49 & 10.66 & 14.59 & 9.30 & 12.98 & 10.85 & 11.04 & NS \\
\hline & & POS & 1.96 & 10.47 & 11.58 & 11.34 & 11.77 & 11.68 & 10.01 & 11.15 & NS \\
\hline & & BS & 9.27 & 10.19 & 9.27 & 10.32 & 12.62 & 15.11 & 9.44 & 12.27 & NS \\
\hline & LSD $\mathrm{P}<0$. & & NS & NS & NS & NS & NS & NS & NS & NS & NS \\
\hline \multirow[t]{5}{*}{ TEB } & $\mathrm{cmol} / \mathrm{kg}$ & $\mathrm{CCS}$ & 2.55 & 0.95 & 2.46 & 1.99 & 1.21 & 2.11 & 1.55 & 1.62 & NS \\
\hline & & FS & 1.37 & 1.45 & 1.78 & 1.53 & 1.62 & 2.49 & 1.61 & 1.91 & NS \\
\hline & & POS & 1.19 & 2.04 & 1.95 & 2.76 & 2.82 & 2.38 & 1.29 & 2.16 & $0.34 *$ \\
\hline & & BF & 0.99 & 2.30 & 2.55 & 1.95 & 1.82 & 3.22 & 3.24 & 2.76 & NS \\
\hline & LSD $\mathrm{P}<0$. & & NS & NS & NS & $0.31 * *$ & NS & NS & NS & $0.31 * *$ & NS \\
\hline \multirow[t]{5}{*}{ TEA } & $\mathrm{cmol} / \mathrm{kg}$ & $\mathrm{CCS}$ & 1.28 & 1.25 & 1.62 & 1.38 & 0.64 & 1.82 & 1.96 & 1.47 & $0.12 *$ \\
\hline & & FS & 1.08 & 0.42 & 1.38 & 0.96 & 1.18 & 0.83 & 1.88 & 1.52 & $0.12 *$ \\
\hline & & POS & 1.65 & 1.41 & 0.99 & 1.34 & 1.20 & 0.59 & 3.63 & 3.89 & $0.12 *$ \\
\hline & & $\mathrm{BF}$ & 1.34 & 1.69 & 1.29 & 1.44 & 1.21 & 0.86 & 2.15 & 1.85 & $0.12 *$ \\
\hline & LSDP $<0$. & & $0.28^{*}$ & $0.28^{*}$ & $0.28^{*}$ & $0.27 *$ & $0.28 *$ & $0.28 *$ & $0.28 *$ & $0.27 *$ & $0.285^{*}$ \\
\hline \multirow[t]{5}{*}{ ECEC Cmol } & $\mathrm{ol} / \mathrm{kg}$ & CCS & 3.74 & 2.74 & 3.72 & 3.40 & 2.73 & 3.26 & 3.44 & 3.14 & $0.43^{*}$ \\
\hline & & FS & 2.81 & 3.66 & 3.05 & 3.17 & 2.79 & 2.99 & 3.48 & 3.06 & $0.43^{*}$ \\
\hline & & POS & 1.96 & 3.54 & 3.04 & 2.85 & 3.70 & 2.97 & 2.80 & 3.16 & $0.43 *$ \\
\hline & & $\mathrm{BF}$ & 2.63 & 3.68 & 3.61 & 3.31 & 2.99 & 2.48 & 4.69 & 3.39 & $0.43^{*}$ \\
\hline & LSD $\mathrm{P}<0$. & & $0.5 *$ & $0.5^{*}$ & $0.5^{*}$ & NS & $0.5^{*}$ & $0.5^{*}$ & $0.5^{*}$ & NS & NS \\
\hline
\end{tabular}

bases, TEA=Total exchangeable acidity, ECEC=Effective cation exchange capacity ,Av.P=Available phosphorus, $\mathrm{C}: \mathrm{N}=\quad \mathrm{Carbon}$ nitrogen ratio, L.U=Land use, TN=Total nitrogen; $\mathrm{CCS}=$ Continuously cultivated soil, FS= Soil Under fallow, POS=Soil under pineapple cultivation, $\mathrm{BF}=\mathrm{Bare}$ fallow, $\mathrm{SL}=$ Sandy loamy; $\mathrm{O} / \mathrm{N}=$ October/November, $\mathrm{D} / \mathrm{J}=$ December/January, F/M=February/ March, A/M=April/May, J/J=June/ July; A.S=August/September. 


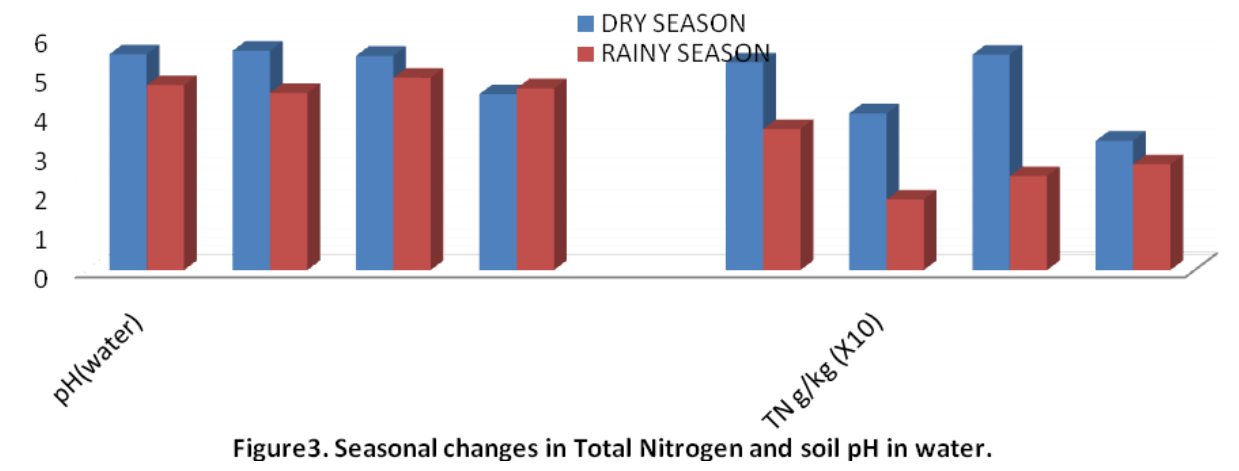

organic matter compared to other land use types they studied. However, the results did not deviate totally because soil organic matter was found to be higher within the months in POS compared to other studied land uses (Table 2 ). High organic matter in CCS could be attributed to addition of organic manure during cultivation. Lower values of soil organic matter found during June/July is attributed to near soil saturation, a condition that favors anaerobic condition that is not comfortable to soil organisms that aid decomposition (Bot and Benites, 2005). Generally, soil organic matter had its peak in December/January, and February/March, increased gradually in April/May, but drastically reduced during June/ July (Table 2). Other factor that may account for the significant negative correlation between SOM and C:N ratio in all the land use types supports the above fact (Figure 7ab). In continuously cultivated soil, SOM had a significant increment around August/September, and December/January suggesting the return of the labile form to the soil, and may be attributed to litter dropping during harvest. Total nitrogen like organic matter was higher during rainy season in all the studied soils (Fig. 3), though it did not follow a particular trend. In continuously cultivated soil, its peak was found still in December $/ J a n u a r y ~(0.65 \mathrm{~g} / \mathrm{kg})$ which gradually increased in February/March, but drastically reduced during June/July $(0.17 \mathrm{~g} / \mathrm{kg})$ and again gradually increased around August/September $(0.54 \mathrm{~g} / \mathrm{kg})$ (Table 2). In FS, the peak was in
February/March $\quad(0.47 \quad \mathrm{~g} / \mathrm{kg}) \quad$ and December $/ J a n u a r y ~ 0.40 \mathrm{~g} / \mathrm{kg}$. The least was found in July/ August $0.07 \mathrm{~g} / \mathrm{kg}$ (Table 2). In POS, the peak was in February/March $(0.56 \mathrm{~g} / \mathrm{kg})$ while the least was in June/July $0.06 \mathrm{~g} / \mathrm{kg}$ (Table 2). Lastly, in BF, the peak was found in December/January $(0.48 \mathrm{~g} / \mathrm{kg})$ and the least was found in June/July sampling $0.23 \mathrm{~g} / \mathrm{kg}$ (Table 2). However, all these values are low in the studied soil (Landon, 1991) thus showing low fertility of soils of the area. The lower nitrogen found during the rainy season is attributed to the high $\mathrm{C}: \mathrm{N}$ ratios recorded within this period and low $\mathrm{pH}$ values which does not encourage organic matter decomposition and the release of nutrients to the soil. The application of liming materials and the incorporation of plant residues that are low in C: $\mathrm{N}$ ratios such as legumes in the soil as mulch will be of significant advantage to organic matter and total nitrogen availability during these periods. This implies that efforts geared towards reducing $\mathrm{N}_{2} \mathrm{O}$ and $\mathrm{CO}_{2}$ emissions from soils by: increasing the efficiency of mineral and organic fertilizers; selection of rational timing and location of application of tillage, and incorporation of plant residues with wide $\mathrm{C}: \mathrm{N}$ ratios will be of immense help towards solving the problem of soil organic matter and nitrogen loss in soils during these periods. Farmers are also advised to make use of the labile forms of organic matter and nitrogen available to them during the first rains for bumper harvest. 
Agim, L.C. ${ }^{1}$, Osuji G.E ${ }^{.1}$, Onweremadu E.U. ${ }^{1}$, Ndukwu B.N. ${ }^{1}$, and Osuaku, S.K ${ }^{2}$.

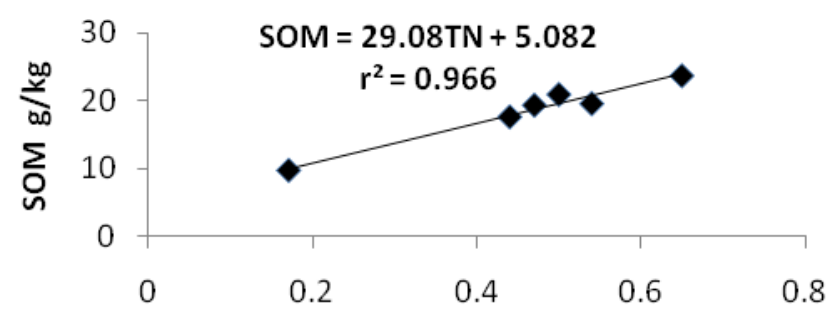

(a) TN g/kg

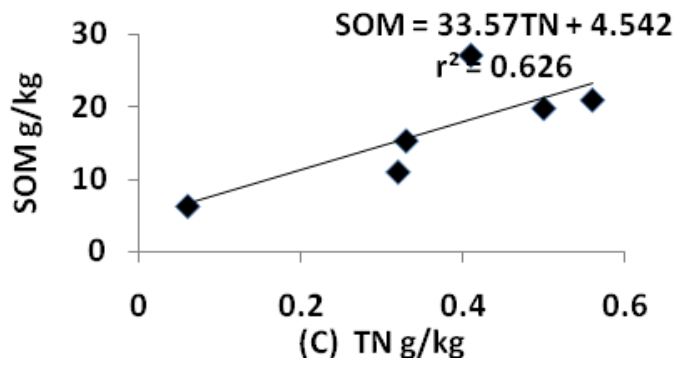

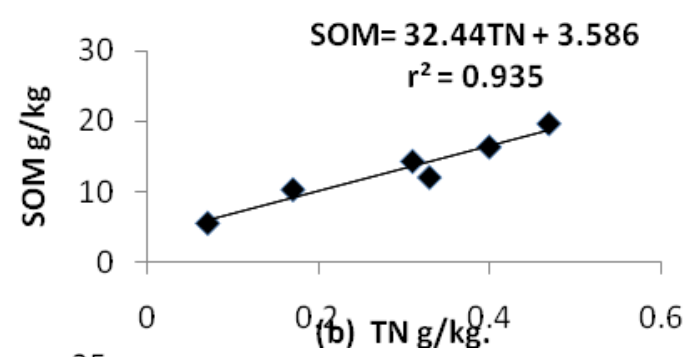

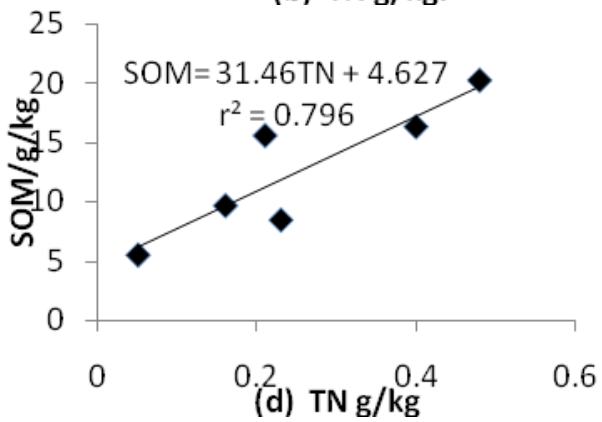

$* *=$ Highly significant $(\mathrm{p}<0.05)$

Figure 4.Relationship and Prediction equations between SOM and TN in (a) CCS, (b)FS, (c)POS and (d) BF respectively.

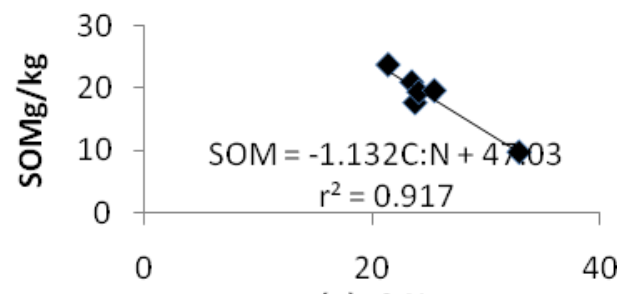

(a) $=\mathrm{C}: \mathrm{N}$

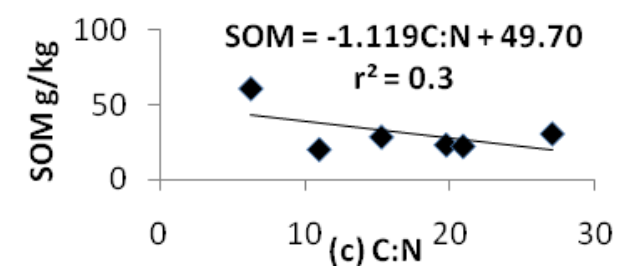

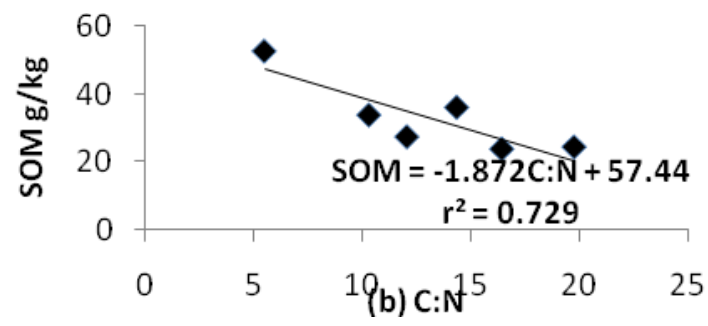

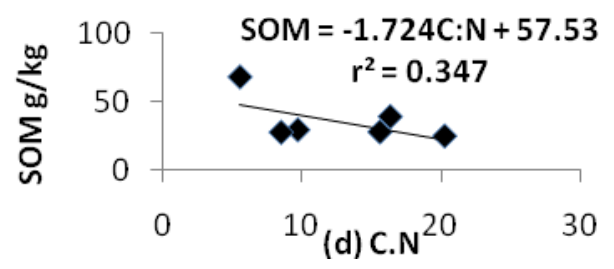

**=Highly significant $(\mathrm{p}<0.05)$

Figure 5 .Relationship and prediction equations between SOM and C:N in (a)CCS, (b)FS, (c)POS and (d) BF, respectively. 


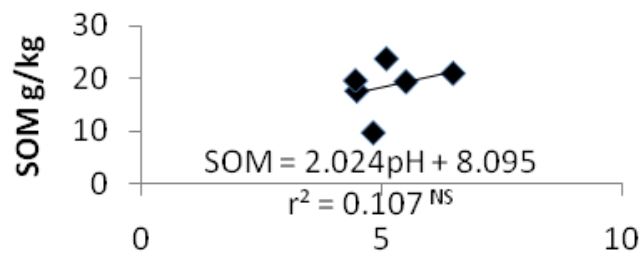

(a) $\mathrm{pH}$ (water)

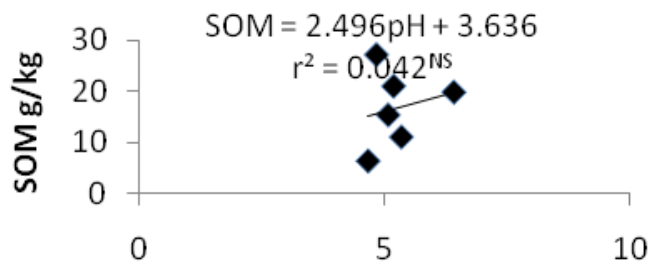

(c) $\mathrm{pH}$ (water)

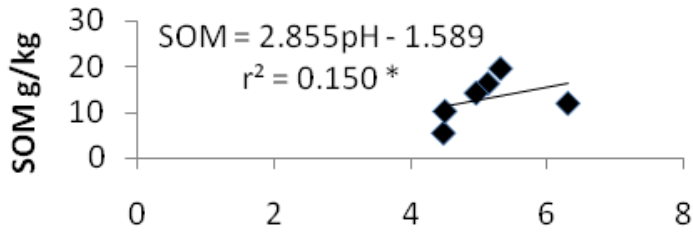

(b) $\mathrm{pH}$ (water)

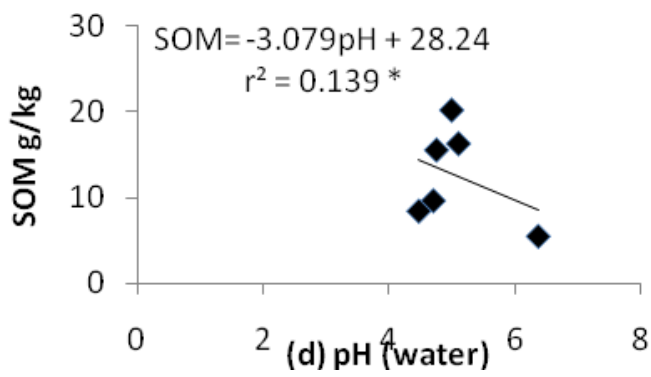

$\mathrm{NS}=$ Not significant, $*=$ significant $(\mathrm{P}<0.05)$.

Figure.6 Relationship and prediction equation between SOM and pH (water) in (a) CCS; (b) FS; (c) POS and (d) BF respectively.

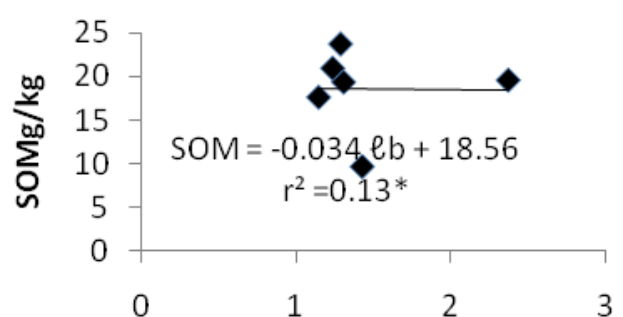

(a) $\ell$ b g/ $\mathrm{cm}^{3}$

RF

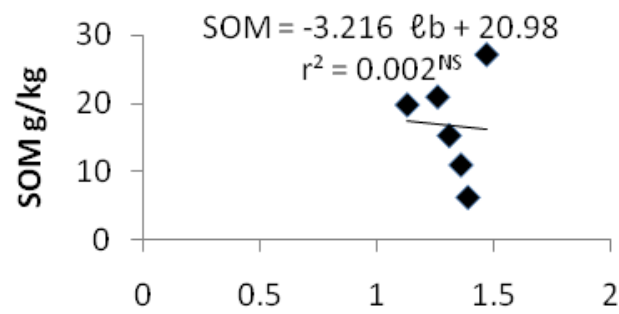

(c) $\ell \mathrm{b} \mathrm{g} / \mathrm{cm}^{3}$

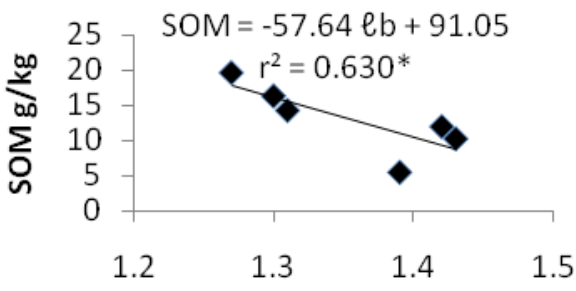

(b) $\ell$ b $\mathrm{g} / \mathrm{cm}^{3}$

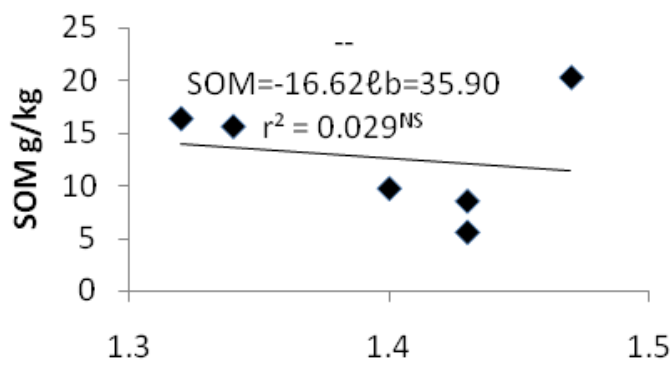

(d) $\ell$ b g/cm3

$\mathrm{NS}=$ Not significant, $*=$ significant $(\mathrm{p}<0.05)$

Figure 7. Relationship and prediction equation between soil orgamic (SOM) and bulk density (p) for (a) CCS; (b) FS; (c) POS and (d) BF respectively.

Agim, L.C. ${ }^{1}$, Osuji G.E ${ }^{1}$, Onweremadu E.U. ${ }^{1}$, Ndukwu B.N. ${ }^{1}$, and Osuaku, S.K ${ }^{2}$. 


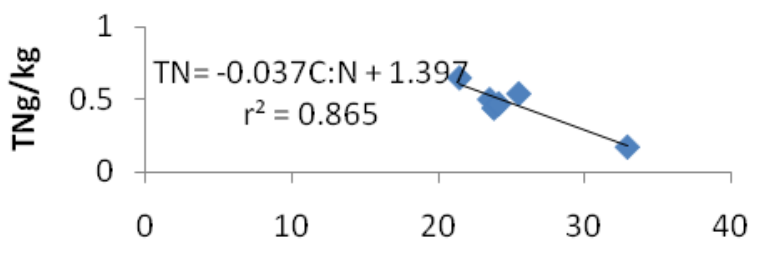

(a) C:N

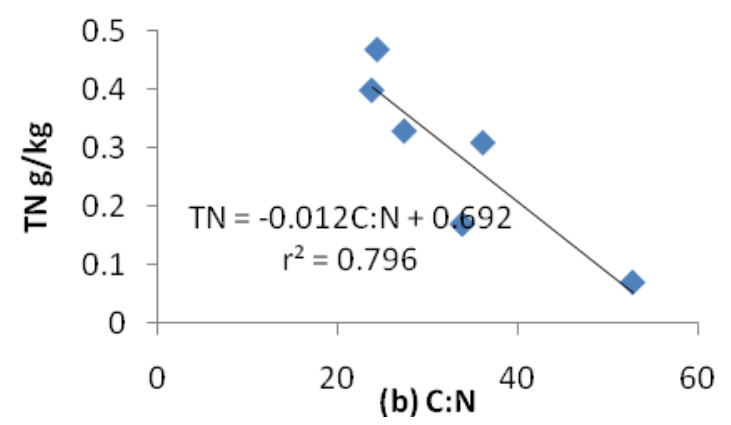

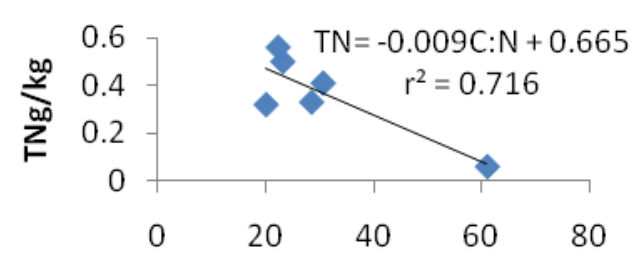

(c) $\mathrm{C}: \mathrm{N}$

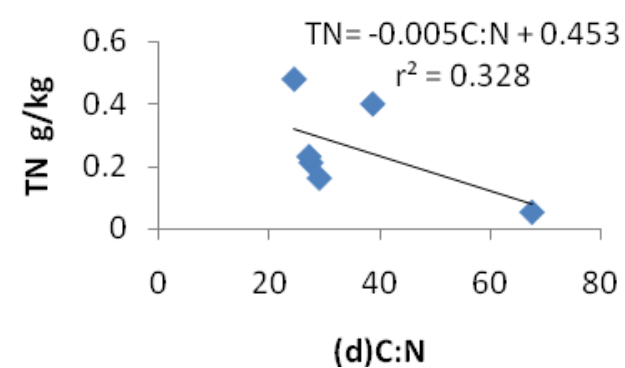

Figure 8. Relationship and prediction equation between TN and C: N ratio in (a) CCS; (b) FS; (c) POS And (d) BF respectively.

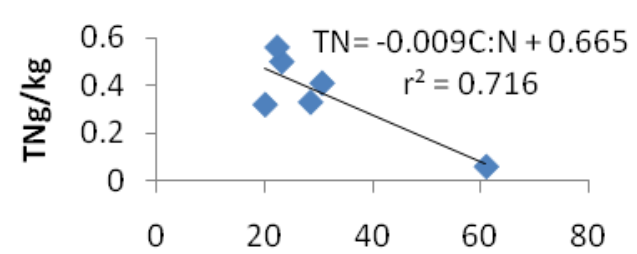

(c) C:N

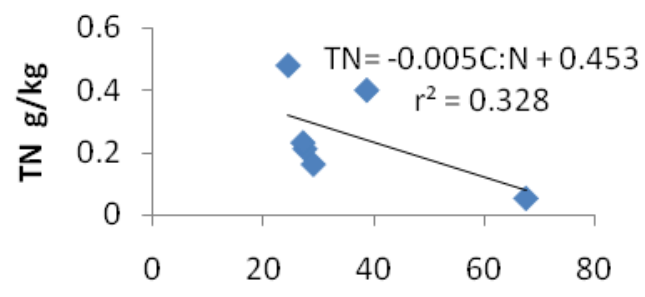

(d) C:N

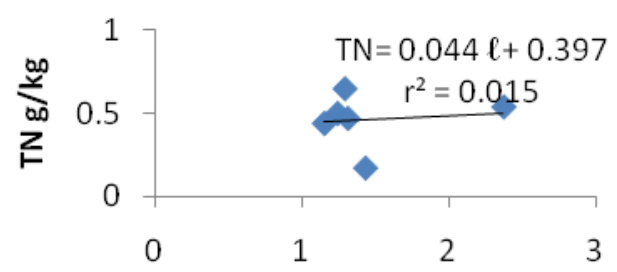

(a) $\mathrm{fg} / \mathrm{cm}^{3}$

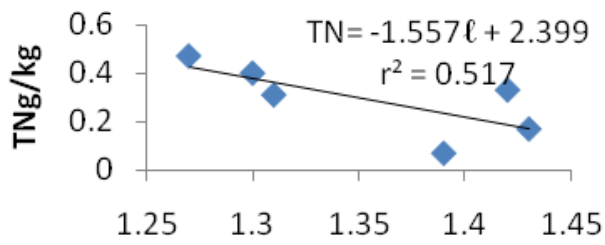

(b) $f \mathrm{~g} / \mathrm{cm}^{3}$

Figure 9. Relationship and prediction equations between TN and Bulk density in (a) CCS; (b) FS; (c) POS; and (d) BF, respectively.

Soil organic matter, total nitrogen availability in relation to selected soil properties.
Organic matter and nitrogen availability in the soil is a function of their relationships to soil $\mathrm{pH}$, 
$\mathrm{C}: \mathrm{N}$ ratio, bulk density among other things (Bot and Benites, 2005). Organic matter had a highly significant $(\mathrm{p}<0.05)$ positive relationship with total nitrogen in all the landuses (Figs. 4 a-d). Unamba-Oparah (1982) and Yao (2010) found significant positive correlation between SOM and TN. The results imply that about $96.6 \%$, $93.5 \%, 62.6 \%$ and $79.6 \%$ of the values of soil organic matter were caused by nitrogen content of the soil all things being equal. Their relationship was stronger in continuously cultivated and fallow soils compared to that of POS and BF. On the contrary SOM had significant negative relations with $\mathrm{CN}$ ratio in all the studied soil (Figs. 5 a-d). This confirms the fact that increase in $\mathrm{C}: \mathrm{N}$ ratio decreases SOM (Bot and Benites, 2005). Similarly Figs. 7 a-d, show that increase in bulk density decreases SOM owing to their negative correlations. This further supports the result found in this study where organic matter was high in dry season and bulk density was low on the contrary. SOM related with soil $\mathrm{pH}$ (water) positively as follows (Figs. 6. a-d). The results were similar to the findings of Unamba-Oparah (1982) and Yao (2010); and showed that increase in SOM increases soil $\mathrm{pH}$. Total nitrogen had significant $(p<0.05)$ negative correlation with $\mathrm{C}: \mathrm{N}$ ratio (Figures 8 a-d). These further buttress the role of $\mathrm{C}: \mathrm{N}$ ratio in nitrogen availability in soils. Unamba-Oparah (1982) found similar results. Total nitrogen related negatively with bulk density in all the studied landuses (Figs. 9 a-d);

\section{CONCLUSION}

The study showed significant increases in soil organic matter and total nitrogen during dry season compared to rainy season in all the landuses studied. Organic matter and total nitrogen have their peaks during January/ February in all the periods; and they gradually increased with rainy season, but had their minimum values during July/August. It was gathered that bare fallow had significant higher bulk density, and lower soil organic matter while Fallow soil and CCS had higher organic matter in comparison to others. This was followed by Fallow soil and Pineapple orchard soil. It was observed that POS had higher SOM and TN in some months. Organic matter and total nitrogen had significant correlation in all the land use types. Equally there were significant but negative relationships between SOM, TN and their C.N Ratios. Farmers are consequently advised to add material that will decay easily in their farms. Farmers are also advised to make use of the early rains in other to maximize the abundance of SOM in its labile form in these periods.

\section{REFERENCES.}

Achmad, R. Anderson, S.H. Gantzer C.J and Thompson A.L. (2003). Influence of long term cropping systems on soil physical factors related to soil erodibility.Soil Sci. Soc. Ame. J. 67: 637-664.

Agboola, A.A. Corey, R.B. (1973). The relationship between soil $\mathrm{pH}$, organic matter, available phosphorus, exchangeable calcium, magnesium and nine elements in the maize tissue, Soil Sci. 115 (5): 367-375.

Akamigbo, F.O.R., Asadu C.L.A. (1983). Influence of parent material on the soil of Southestern Nigeria. East Africa Agric. For. J. 48: 82-91.

Akamigbo, F.O.R. (1999) .Influence of land use on soil properties of the humid Tropical agro ecology of southeastern Nigeria Agric J., 30:59-76.

Angers, D. A. (1992). Changes in soil aggregation and organic carbon under corn and alfalfa. Soil Sci. Soc. Am. J., 56: $1244-1249$.

Anikwe, M.A.N.(2010). Carbon storage in soils of Southeastern Nigeria under different management practices. Carbon Balance and Management, 5:5 doi:10.1186/1750-0680-5-5.

Balesdent, J. and Balabane, M. (1992). Maize root-derived soil organic carbon estimated by natural 13C abundance, Soil Biol. Biochem., 24:97-101.

Batjes, N.H. Dijkshoorn, J.A. (1999). Carbon nitrogen stocks in the soil of Amazon Region. Geoderma 89: 273-286.

Brady, N.C and Weil, R.R. (1999). Nature and properties of Soils12 ${ }^{\text {th }}$ ed, Prentice Hall inc, New Jersey.

Bremner, J. M. (1996). Nitrogen total. Sparks, D. L., (Ed.). Methods of soils analysis, part 3, chemical method. 2nd. Ed, SSSA Book Series No. 5, SSSA, Madison, W.I. 1085-1121.

Bresson, L.M. Moran, C.J., Assouline, S. (2004). Use of bulk density profiles from $\mathrm{X}$

radiography to examine structural crust models. Soil Sci. Soc. Am. J., 68: 1169-1176.

Bot, A., and Benites, J. (2005). Important of soil organic matter, Key to droughtresistant soil and sustained food production, FAO Soil Bulletins Rome.

Cambardella, C.A., and Elliott, E .T. (1992). Carbon and Nitrogen Dynamics of Soil Organic Matter Fractions from Cultivated Grassland Soils. Soil 
Science Society of America Journal: 58, Issue: 1: 123-130.

Chukwuma, M. C.; Eshett, E. T.; Onweremadu, E. U.; Okon, M. A. (2010). Study of zinc availability in a crude-oil-polluted Eutric tropofluvent. Int. J. Environ. Sci. Tech., 7 (2): 1-10.

Crocker, G. J. and Holford, I. C. R. (1996). The Tamworth legume/cereal rotation, in

Evaluation of Soil Organic Matter Models Using Existing Long-Term Databases, D. S. Powlson, P. Smith, and J. U. Smith (Eds.), Springer-Verlag, New York. NATO ASI Ser. I, vol. 38: 313- 317.

Dabek-Szreniawska M., and Balashov, E .(2007). Seasonal changes in labile organic matter, mineral nitrogen, and $\mathrm{N}_{2} \mathrm{O}$ emission in a loamy sand Orthic Luvisol cultivated under three management practices. Int., Agrophysics, 21: 127-132.

Eshett, E. T.; Omueti, A. I.; Juo, A. S. R. (1990). Physicochemical, morphology and clay mineralogical properties of soils overlying basement complex rocks in Ogoja, northern cross river State of Nigeria. Soil Sci. Plant Nutr., 36 (2): 203-214.

Eswaran, H. Berg, E.V and Reich P. (1993). Organic carbon in soils of the world Soil Science Society of American Journal, 57: 192-194.

Forth, H.D.(1984). Fundamentals of Soil Science. $7^{\text {th }}$ ed, John Willy and Sons Publishers, New York.

Gee ,G.W. and Or, D. (2002). Particle Size analysis. In methods of soil analysis.(Dane .D.J.,and G.C Topps Eds), Part 4. Physical methods. Soil Science society of America Book Series No. 5, ASA and SSSA. Madison, W.I.225-293.

Grossman, R.B.and,Reinsch, T.G. (2002). Bulk Density and Linear Expansivity. In: Methods of Soil Analysis,( Dane, J.H., and G.C.,Topps Eds),part 4,Physica methods. Soil Sci, Soc, Am. Book Series No. 5 ASA and SSSA Madison W.I. 201-228.

Hendrix, P. F. (1997). Long-term patterns of plant production and soil carbon dynamics in a Georgia Piedmont agroecosystem. In Soil Organic Matter in Temperate Agro ecosystems : (Ed., E. A. Paul), Long-Term Experiments in North America, , CRC Press, Boca Raton, Fla.235-246.

Hendershort, W.H., Lalande, H., and Duquette, M., (1993). Soil reaction and exchangeable acidity, In: Soil sampling and methods of soil analysis, (Carter M.R., Ed.), Canadian Soc.Soil Sci. Lewis Publishers, London ,141-145.

Howarth, R. W. (1996). Regional nitrogen budgets and Rive-rine $\mathrm{N}$ and $\mathrm{P}$ fluxes for the drainages to the North Atlantic Ocean: Natural and human influences. Biogeochemistry 35: 75-139.

Igbozurike, M.U. (1975). Vagetation Types. In: Nigeria in Maps,( G.E.K., Ofomata Ed.) Eastern States. Ettiope Publishing House. Mid West Mas Communication Corporation, Benin City, Nigeria.30-32.

Imo State of Nigeria (1984), Atlas of Imo State, Ministry of Works and Transport,

Department of Land Survey and Urban Development.

Jackson, R. B. Schenk, H. J. Jobba'gy, E. G. Canadell, J. Colello, G. D. Dickinson, R. E. Field, C. B. Friedlingstein, P. Heimann, M. Hibbard, K. Kicklighter, D. W. Kleidon, A.Neilson, R. P. Parton, W. J. Sala, O. E. and Sykes. M. T. (2000). Below ground consequences of vegetation change and their treatment in models. Ecological Applications 10:470-483.

Kieft, T. L. White, C. S. Loftin, S. R. Aguilar, R. Craig, J. A. and Skaar D. A. (1998).

Temporal dynamics in soil carbon and nitrogen resources at a grassland-shrubland ecotone, Ecology, 79: 671-683.

Knops J.M.H. and Tilman D. (2000). Dynamics of Soil Nitrogen and Carbon Accumulation for 61 years after Agricultural Abandonment. Ecological Society of America 81(1): 88-98.

Landon, J.R. (1991). Booker tropical soil manual: A hand book for soil Surveyors and

agricultural land evaluation in the tropics .Paperback edition, Long man Scientific and Technical .U.K.

Leinweber, P. Schulten, H. and Ko"rschens, M. (1994). Seasonal variations of soil organic matter in a long-term agricultural experiment, Plant Soil, 160: 225- 235.

Mann, L. K. (1986). Changes in soil carbon storage after cultivation. Soil Science 142:279-288

Mahmood, T. Azam, F. Hussain, F.and Malik, K. A. (1997). Carbon availability and microbial biomass in soil under an irrigated wheat-maize cropping system receiving different fertilizer treatments, Biol. Fertil. Soils, 25:63-68.

McLean, E.V. (1982). Aluminium,. In: Page, A.L., Miller, R.H. and Keeney, 
D.R.(eds.). Methods of Soil Analysis, Part 2, Am. Soc. Agron, Madison, WI. 978-998.

Nelson ,D.N., and Sommers L.E. (1982).Total Carbon, organic carbon and matter In: methods of soil analysis part 2.( Page A.L., R.H., Miller, and D.K., Keeney

Eds.).Amer. Soc. Agron. D.M.Madison, W.I: 539-579.

Obi, M.E., (1990). Soil physics. A compendium of lectures. Department of Soil Science, U.N.N. 103.

Ofomata, G.E.K. (1975).Soils. In Nigeria in Maps:( Ofomata, G.E.K Ed.,) Eastern states. Ettiope Publishing House. Mid West Mass Communication Coorporation, Benin City, Nigeria: 3032.

Onweremadu, E. U. (2007). Pedology of near gully sites and its implications on the erodibility of soils in central SouthEastern Nigeria. Res. J. Environ. Sci., 1 (2): 71-76.

Onweremadu, E.U., Eshett, E.T., Osuji, G.E. (2007). Temporal variability of selected heavy metals in automobile soils. Int. J. Environ. Sci. Tech., 4 (1), 35-41.

Onweremadu E.U. Oti, N.N. Imadojemu, P.E. Opara, C.C. Agim, L.C. and Chukwuma, M.C. (2008). Physico chemical characterisations of some soils in Edo State, Nigeria.Proc. $42^{\text {nd }}$ Annual Conf. Agric. Soc. Nig.Ebonyi State. 458-461.

Orajaka, S. O. (1975). Geology. In: Nigeria in maps: Eastern States (Ofomata, G. E. K. Ed.). Ethiope Publishers. Benin city Nigeria, 5-7.

Oti, N,N, (2002). Discriminant functions for classifying erosion degraded lands at Otamiri, Southeastern Nigeria. AgrioSci; 3 (1): 43-40.

Schlesinger, W. H. (1986). Changes in soil carbon storage and associated properties with disturbance and recovery In: ( J. R. Trabalka and D. E. Reichle, Eds.). The changing carbon cycle: A global analysis. Springer
Verlag, New York, New York, USA. 194-22.

Scott, H.D. Mauromoustakos, A. Handayani, I.P.and Miller D.M. (1994). Temporal variability of selected properties of Loessial soil as affected by cropping. Soil Sci. Soc. Am. J. 58:15311538.

Singer J.M., and Munns, W.D. (1996) .Soils .An Introduction, (3rd edition,) Prentice Hall-Inc. New Jersey.

Tiessen, H. J., Stewart, J. W. B. and Bettany, J. R. (1982). Cultivation effects on the amounts and concentration of carbon, nitrogen, and phosphorus in grassland soils. Agronomy Journal, 74: 831-835.

Unamba-Oparah, I. (1982). Comparison of the carbon and nitrogen contents and their relationships to other soil properties in some important soils of Southeastern Nigeria. Beitrage trop. Landwirtsch. Veterinarmed, 20, H.2: 167-176.

Unamba-Oparah, I.; Wilson, M. J.; Smith, B. F. L. (1987). Exchangeable cations and mineralogy of some selected Nigerian soils. Appl. Clay Sci., 2: 105-128.

Wang, J., Fu, B., Qui, Y., Chen, L.(2001) .Soil nutrients in relation to land use and landscape position in the semi-arid small catchment on the loess plateau in china. J. Arid Environ, 48: Pp., 537550.

Woomer, P.L., Ingram, J.S.J. (1990). The biology and fertility of tropical soils. The Tropical Soil Biology and Fertility Report, Nairoby, Kenya.

Yao, M.K, Angui, P.K.T, Konaté, S.. Tondoh, J. E. Tano. L., Abbadie., Benest, D. (2010). Effects of Land Use Types on Soil Organic Carbon and Nitrogen Dynamics in Mid-West Côte d'Ivoire. European Journal of Scientific Research, Vol.40 No.2 :211-222 .

Xiao, H., (1999). Climate Change in Relation to Soil Organic Matter. Soil and Environmental Sciences 8, (4): 300304. 